\title{
RELEVANSI PERJANJIAN LAMA BAGI KEHIDUPAN GEREJA MASA KINI
}

\author{
Evendy Tobing
}

\section{PENDAHULUAN}

Pertanyaan mendasar bagi kita dalam mempelajari Perjanjian Lama adalah: apakah Perjanjian Lama masih relevan bagi kehidupan kita masa kini? Jika Perjanjian Lama masih relevan, bagaimana menerapkannya? Untuk memahami relevansi Perjanjian Lama bagi kehidupan dan pelayanan gereja masa kini, maka dalam tulisan singkat ini penulis memaparkan antara lain: probelamatika studi Perjanjian Lama, Isu-isu theologis yang berkembang mengenai relavansi Perjanjian Lama sepanjang sejarah, landasan theologis sebagai dasar relevansitas Perjanjian Lama untuk masa kini serta pengajaran-pengajaran berharga dari Perjanjian Lama yang relavan bagi kehidupan dan pelayanan gereja masa kini

\section{PROBLEMATIKA STUDI PERJANJIAN LAMA}

Tidaklah berlebihan jika para penulis menggambarkan Perjanjian Lama sebagai "tambang emas" yang tidak ada habis-habisnya dalam bertheologia. Jeohn Gwang-Ho seorang theolog dan juga seorang ilmuwan dari Korea Selatan mendaftarkan kekayaaan-kekayaan yang terdapat di dalam Perjanjian Lama sebagai berikut.

Perjanjian Lama berisi tentang asal-usul Kosmos, Perjanjian Lama berisi tentang asal-usul keteraturan dan keruwetan, Perjanjian Lama berisi tentang asal-usul Tata Surya, Perjanjian Lama berisi tentang asal-usul Angkasa dan Air, Perjanjian Lama berisi tentang asal-usul Kehidupan, Perjanjian Lama berisi tentang asal-usul Manusia, Perjanjian Lama berisi tentang asal-usul Dosa, Perjanjian Lama berisi tentang asal-usul Bahasa, Perjanjian Lama berisi tentang Sistem, Perjanjian Lama berisi tentang Kebudayaan, Perjanjian Lama berisi tentang asal-usul Suku yang terpilih, dll. ${ }^{1}$

Contoh lain yang menjelaskan peran teks Perjanjian Lama ditulis oleh seorang psikolog Batara Pane yang memakai Perjanjian Lama sebagai \footnotetext{
t.t), 1 .

Jeohn Gwang-Ho, Saints Penciptaan (Bandung: Institut Alkitab Tiranus,
} 
acuan dalam memikirkan kiat-kiat yang paling manjur dalam menghadapi teknologi seks. ${ }^{2}$ Dalam majalah yang sama dengan edisi yang berbeda ditulis oleh Daltur Rendakasiang, seorang politikus juga merujuk kepada Perjanjian Lama sebagai suatu usaha untuk menciptakan Good Governance di tengah-tengah situasi bangsa yang memiliki pemimpin yang korup ${ }^{3}$. Tulisan-tulisan ini memberikan indikasi bagi penulis bahwa Perjanjian Lama memberikan kontribusi yang sangat berarti dalam berbagai aspek kehidupan manusia.

Tetapi pada sisi yang lain dari apa yang penulis kemukakan di atas, dapat dinyatakan bahwa minat orang percaya terhadap Perjanjian Lama sangatlah memprihatinkan. Kondisi ini bukan saja menggerogoti orang percaya secara umum, tetapi juga para theolog. Tidaklah berlebihan apa yang diuraikan oleh John Stott mengenai hal ini, "barangkali area Alkitab yang paling banyak dilalaikan pengkhotbah masa kini adalah Perjanjian Lama."4 Jika Perjanjian Lama dipakai dalam khotbah, maka hanyalah bagian-bagian tertentu saja seperti Kejadian, Mazmur, Amsal. Perjanjian Lama sebenarnya merupakan ladang yang matang bagi studi theologia dan proklamasi Injil. Tetapi dalam kenyataan kurangnya minat terhadap Perjanjian Lama sering kali didasarkan atas berbagai alasan.

John Stott dalam bukunya The art of Preaching in Twentieth century Between Two Worlds, menguraikan beberapa alasan mengapa Perjanjian Lama dilalaikan dalam khotbah pada masa kini. ${ }^{5}$ Kurangnya minat orang

\footnotetext{
${ }^{2}$ Batara Pane, "Berlarilah seperti Yusuf dari Istri Potifar." Majalah Triwulan DIA (Jakarta:Yayasan Perkantas, edisi no.3 tahun ke XVII/2002) 14-16.

Daltur Rendakasiang, "Mengubah katak menjadi Daniel." Majalah Triwulan DIA (Jakarta:Yayasan Perkantas, edisi no.4 tahun keXVII/2002), 21.

$4 \quad$ John R.W. Stott, The art of Preaching in Twentieth century Between Two Worlds (Grand Rapids, Michigan: William Eerdmans Publishing Company, 1982), 124.

$5 \quad$ Antara lain diuraikan enam alasan: 1) Penyangkalan inspirasi Alkitab (High Criticism) secara khusus Perjanjian Lama. Perubahan dari kesempurnaan, ketidaksalahan, otoritas (absolut) kepada kritik-kritik yang menganggap Alkitab (Perjanjian Lama) penuh dengan kesalahan (kontradiksi) sehingga melalaikan Perjanjian Lama, 2) Perjanjian Lama yang merupakan dasar pemberitaan adalah ide manusia semata walaupun dikemas dalam bentuk indah. Firman Allah (Perjanjian Lama) merupakan fiksi yang tidak memiliki otoritas apa-apa, 3) Ketidak percayaan terhadap Perjanjian Lama, mengakibatkan para pengkhotbah tidak menerima apa-apa. Jika Perjanjian Lama dikhotbahkan, maka dianjurkan khotbah dalam bentuk topikal yang memiliki kedangkalan isi Alkitab atau konteks, 4) Nilai Perjanjian Lama bagi orang percaya tidak jelas. Perjanjian Lama hanya merupakan teori yang menunjukkan sesuatu yang berbeda pada masa kini sehingga Perjanjian Lama tidak relevan kepada dunia masa kini. Sulit membuat suatu materi dari Perjanjian Lama untuk kebutuhan manusia modern, 5) Tidak percaya terhadap keajaiban yang dituliskan dalam Alkitab (Perjanjian Lama). Jika seseorang tidak percaya terhadap mujizat, akan sulit mengkhotbahkan Perjanjian Lama. Peristiwa Nuh (Air Bah, Kej 6), tulah di Mesir (Kel 7-12), penaklukan Yeriko (Yos 6), Daniel di gua singa (Dan 6:14-28). Mujizat ditunjukkan dalam hidup dan pelayanan manusia-manusia yang
} 
percaya secara umum dan mahasiswa theologia secara khusus merupakan pemandangan yang lazim kita lihat. Keadaan ini menimbulkan pertanyaan apa yang menyebabkan hal ini terjadi?

Mempelajari Perjanjian Lama, berarti mempelajari sejarah masa lalu, mempelajari dunia yang berbeda dengan konteks kita masa kini. Perbedaan ke dua zaman ini menjadi akar persoalan dalam studi Perjanjian Lama. Menemukan arti suatu teks dan makna ayat itu pada masa kini merupakan masalah mendasar dalam theologia Perjanjian Lama. Tentang hal itu Erickson berpendapat:

One problem of particular concern to the Theologian, and of course to the entire Christian church, is the apparent difference between the world of the Bible and present world. Not only the language and concepts, but in some cases the entire frame of reference seems so sharply different. We begin this chapter by describing an extreme view of the difference. ${ }^{6}$

Seorang theolog Jerman, Gotthold Ephraim Lessing (1729-1781) mengatakan: terdapat 'jurang yang ngeri' antara dunia Alkitab (teks asli, arti asli) dengan dunia masa kini yang tidak mungkin dapat dijembatani, sehingga tidak mungkin bagi kita untuk mencari arti dari suatu teks (arti asli) dan maknanya bagi kehidupan masa kini. ${ }^{7}$ Pemikiran Lessing ini melahirkan relativisme historis yang kemudian dikembangkan oleh Friedrich Schleiermacher (1768-1874). Pandangan ini dikutip oleh Boeker antara lain,

Pengertian akan Allah tidak terdapat dalam pembacaan Alkitab. Tiap-tiap orang terikat oleh pra-pengertiannya dan tidak mungkin masuk ke dalam pengertian sama dengan penulis zaman dahulu. Maksud yang berarti bagi kita adalah maksud yang kita temukan dalam teks terlepas dari konteks dan maksud asli. ${ }^{8}$

Sejalan dengan perkembangan itu, ilmu Anthropologi menemukan sekian banyak manusia di bumi dengan keaneka ragaman kebudayaan dan

dipilih Allah. (Nabi-nabi, imam-imam, Raja-raja dll). 6) Pendengar-pendengar yang membosankan. Bagian-bagian kitab Perjanjian Lama yang panjang, dan bentuknya yang tidak menarik (silsilah, hukum-hukum, kronologi-kronologi, daftar dan lain), tidak pernah disentuh dan dikhotbahkan; John R.W Stott, The art of Preaching in Twentieth century Between Two Worlds (Grand Rapids, Michigan: William Eerdmans Publishing Company, 1982), 125.

Millard J. Erickson, Christian Theology. Vol 1 (Grand Rapids: Baker Book House, 1983), 105-106.

$7 \quad$ Richard L. Pratt, Jr., He Gaves Us Stories (Ia Berikan Kita Kisah-Nya) (trans) (Surabaya: Momentum, 2005), 259.

1991), 28

T. Boeker, Theologia Perjanjian Lama (Batu: Institut Injil Indonesia, 
sistem penghargaan yang melahirkan filsafat relativisme budaya. Pandangan Barr, yang dikutip oleh Pratt antara lain menulis:

Segala karya atau teks yang disusun di zaman kuno dengan kultur kuno bermakna di zaman dan kebudayaan waktu itu; di zaman atau kebudayaan kita bisa berbeda maknanya, atau malah tak bermakna sama sekali... Karya seperti Alkitab, yang adalah produk dari budaya tertentu (atau lebih tepatnya, adalah kumpulan karya tulis, produk suatu group pada situasi kondisi saat itu selama suatu masa perubahan yang panjang) sulit dikatakan otoritatif secara tegas bagi kultur budaya yang berbeda; idenya begitu absurd sehingga tidak berharga untuk didiskusikan. ${ }^{9}$

Konsep relativisme kebudayaan dan relativisme sejarah merupakan satu kendala dalam penafsiran Alkitab masa kini. Tentang hal itu Wahono mengutip pandangan Barr antara lain, bahwa tidak ada sifat manusia yang universal, sehingga peraturan-peraturan yang berlaku untuk satu kebudayaan sama sekali tidak bisa digunakan dalam konteks yang lain. ${ }^{10}$ Arti dan nilai-nilai yang berlaku untuk masa kini sangat berbeda dari arti dan nilai pada jaman kuno. Dengan demikian kita tidak mungkin dapat memahami arti asli dari satu teks.

\section{A. Isu-Isu Theologis Tentang Relevansi Perjanjian Lama}

Perdebatan mengenai relevansi Perjanjian Lama sudah berakar pada studi theologia itu sendiri dari masa ke masa, bahkan jauh sebelum itu di dalam Alkitab sendiri (PL dan PB), isu-isu tersebut sudah eksis. Dalam tulisan ini hanya akan dipaparkan isu-isu relevansi Perjanjian Lama pada Gereja Mula-Mula dan era munculnya historis kritis.

Pada Abad Gereja Mula-Mula tantangan tentang relevansi Perjanjian Lama berasal dari Marcion yang membuat pemisahan kekristenan dari Perjanjian Lama. Para Bapa gereja mula-mula memakai Perjanjian Lama untuk mempertahankan iman dan sebagai sumber suatu sumber bagi pengajaran mereka, tetapi dalam penerapannya mereka sering berusaha untuk lebih menekankan penafsiran alegori dan tipologi. ${ }^{11}$ Alexandrine yang terkenal melalui karya Origenes yang memiliki tujuan untuk menemukan dalam Perjanjian Lama seluruh doktrin Kristen dengan menerapkan penafsiran Alegoris. ${ }^{12}$ Theologia Anthiokia yang

\begin{tabular}{cl}
\hline 9 & Pratt, Jr., He Gaves Us..., 360. \\
10 & Wismoadi Wahono, Disini Kutemukan (Jakarta: BPK Gunung Mulia, \\
$\begin{array}{c}\text { 1987), } 34 . \\
11\end{array}$ & Ralph L Smith, Old Testament Theology, Its History, Method and \\
Message (Nashville, Tennese: Broadman \& Holman Publisher, 1985), 25. \\
According Origen Scripture has three Meanings which correspond to the
\end{tabular}


dipresentasikan melalui tokohnya Diodere of Tarsus (330-392) sebaliknya menekankan kepada makna harafiah dari suatu teks Alkitab. Sebagai pertentangan dengan pandangan Origen antara lain ia menulis, the Theoria does not change history, but is superimposed upon it; thus in one and the same text certain features refer to events of author's own time, others to Christ. ${ }^{13}$ Theodurus mengartikan hubungan Perjanjian Lama dengan Perjanjian Baru terutama sebagai perkembangan historis.

Isu-isu tentang relevansi Perjanjian Lama juga menjadi salah satu kendala yang muncul melalui pendekatan historis-kritis terhadap Perjanjian Lama. Hayes dalam bukunya antara lain menulis,

Aplikasi pendekatan historis-ritis dan sejarah agama-agama kepada Alkitab secara efektif memangkas klaim-klaim tradisional yang telah dibuat mengenai kesatuan, otoritas, inspirasi, kualitas penyataan, dan kekhasan Perjanjian Lama. Perjanjian Lama bukanlah satu karya yang diinspirasikan dengan statement-statement yang infalible, gambaran-gambaran historis yang dapat diandalkan, kebenarankebanaran yang bersifat transendental, prespektif-prespektif yang utuh, dan isi yang unik. Tetapi jika Perjanjian Lama dilihat berdasarkan pandangan historis kritis, maka terbukti Perjanjian Lama hanya sebagai suatu kitab yang sangat manusiawi, terikat waktu kepada koneks-konteks jauh di masa lalu, terdiversifikasi dan kontradiktif dalam isinya, bersifat primitif dalam pandangan ilmiahnya, fakta-fakta historisnya tidak akurat dan memiliki persamaan-persamaan dengan literatur-literatur kebudayaan pada masa lalu. ${ }^{14}$

Dengan demikian jelaslah bahwa persoalan-persoalan relevansi Perjanjian Lama adalah suatu problematika theologis yang telah muncul, berkembang sampai saat ini pada tahapan kritis

\section{B. Relevansi Perjanjian Lama Dalam Perjanjian Lama dan Perjanjian Baru}

Persoalan dasar tentang relevansi adalah bagaimana dialog antara Allah dan manusia yang terjadi dan dicatat dalam bahasa dan gagasan aktual pada era kuno di Palestina dapat didengar, dipahami secara aktual dan masuk ke dalam dunia moderen. Dengan demikian persoalan

three parts human body and to the three categories of believers : the body of is the letter visible to all eyes, the soul is the hidden meaning contained in the letter, lastly, the spirit is heavenly things which the letter represents, Edmond Jacob, Theology of the Old Testament (London: Hodder Stoughton, 1958), 14.

13 Jacob, Theology of the..., 15.

14 John H. Hayes \& Frederick Prussner, Old Testament Theology, its History \& Development (Atlanta: John Knox Press, 1985), 144. 
hermeneutik masuk ke dalam persoalan relevansi Perjanjian Lama bagi iman Kristen. Jika Perjanjian Lama relevan (juga Perjanjian Baru), bagaimana menjelaskan relevansi itu. Pandangan J. Coert Bylaars sebagaimana dikutip oleh Mayo, menyatakan pentingnya hermeneutika dalam memahami Perjanjian Lama sebagai jembatan yang menghubungkan kedua dunia yang sangat berbeda itu. Lebih lanjut ia mencatat:

\begin{abstract}
Manusia secara umum dapat melihat kepada Alkitab hanya melalui satu cara tetapi orang Kristen dapat melihat kepada Alkitab dengan dua cara. Pada tempat pertama, layaknya seluruh manusia, orang Kristen dapat membaca Alkitab sebagai laporan penting tentang atau sebagai tradisi agama Kristen-Yahudi. Alkitab adalah produk tentang suatu sejarah iman (Historic Faith). Pada bagian ini dilaporkan tentang suatu kegerakan agama dalam suatu periode sejarah yang panjang. Alkitab memiliki nilai educational baik untuk orang Kristen maupun bagi manusia pada umumnya. Alkitab dimiliki sebagai produk budaya, yang memperkenalkan kita kepada suatu kehidupan pada masa lalu. Dalam pemahaman yang kedua (khusus bagi orang percaya), orang-orang Kristen dapat juga melihat kepada Alkitab sebagai kitab penyataan, nilainya tidak hanya bersifat educational, tetapi memiliki otoritas. Dalam kasus yang kedua ini, orang Kristen tidak datang kepada Alkitab, tetapi Alkitab yang datang kepada mereka. Alkitab bukan hanya suatu laporan yang panjang tentang masa lalu, tetapi suatu dinamika realitas masa kini. ${ }^{15}$
\end{abstract}

Alkitab merupakan medium yang mempertemukan Allah dengan manusia, Alkitab adalah kitab iman pribadi yang menjelaskan "nasib" manusia. Alkitab memberikan kepada kita cermin untuk melihat masa depan. Alkitab menjalin iman dan sejarah.Tetapi persoalannya ialah bagaimana mendamaikan keduanya. Kecenderungan yang timbul ialah Alkitab dipakai hanya sebagai laporan tentang iman sejarah dan bukan sebagai kitab penyataan. Sebagai orang Kristen harus mengintegrasikan kedua-duanya pada waktu yang sama. Bagaimana orang Kristen membaca dan memakai keduanya secara bersama, harus dihubungkan dalam usaha untuk menafsirkan Alkitab secara konstruktif bagi iman Kristen.

Mengacu kepada pernyataan tersebut di atas, untuk memahami relevansi PL harus dimulai dari PL itu sendiri (juga dalam PB), hal ini nampak pertama-tama dalam tulisan penulis-penulis PL. Secara lebih rinci hal ini ditulis oleh Smith dalam bukunya sebagai berikut.

Later Writer in Old Testament used some of its earlier writings theologically. Zechariah referred to teachings of the "former prophets" several times (see Zech 1:4; 7:7,12). Hagai must have

15 Mayo, M.S, The Relevance of Old Testament for Christian Facts (America: University Press,1981), 35. 
known about Jeremiah's prophecy that God would remove His "signet ring" from the hand of Coniah (Jer 22:24-25) when he said God would make Zerubabel, Coniah's grandson, like a signet ring (Hag 2:23). Jeremiah spoke about a new covenant (Jer 31:31-34). Other Prophets spoke of a new Exodus (Isa 43:14-21; 48:20; 52:12) and a new David (Jer 23:5-6; Ezek 34:23-24; 37:24-27) The forerunner of the Mesiah would be a "coming" of Elijah (Mal 4:-56). ${ }^{16}$

Perjanjian Lama diyakini dan dihargai pada zaman Perjanjian Lama itu sendiri sebagai penyataan Allah dan dipakai oleh para penulis pada zamannya yang terdahulu sebagai suatu sumber theologia kitabnya (Mzm 78; Jer 26:18; Ezr 7:10; Neh 8:1-8). ${ }^{17}$ Memasuki masa Intertestament theologia Perjanjian Lama tetap eksis, pemahaman dan penghargaan penulis Perjanjian Lama terhadap otoritas Perjanjian Lama yang nampak dalam frase, "seperti yang tertulis""18 dalam berbagai versi di berbagai tempat dalam Perjanjian Lama juga nampak di dalam karya para penulis masa itu. ${ }^{19}$ Komunitas Qumran menafsirkan bahan-bahan dari Perjanjian Lama. Mereka menulis beberapa tafsiran atau himne yang didasarkan kepada tema-tema dari Perjanjian Lama. Mereka melihat hidup mereka sendiri sebagai kehidupan pada akhir zaman dan mereka mempercayai bahwa Perjanjian Lama akan digenapi di dalam pengalaman mereka. ${ }^{20}$

Penulis Perjanjian Baru, memakai Perjanjian lama secara theologis, dua puluh tujuh kitab dalam Perjanjian Baru menunjukkan hubungan secara langsung dengan Perjanjian Lama. Yesus Kristus secara konsisten berbicara tentang Perjanjian Lama sebagai dasar dan penjelasan bagi pengajaran dan pelayanan-Nya (Mat 5:17; Luk 17, 21; 24:27). Penulis Perjanjian Baru (para Rasul) mempelajari Perjanjian Lama sebagai nubuatan keselamatan (Kis 3:24). Mereka menekankan kebenaran tentang berbagai aktivitas Allah dalam sejarah Israel (Kis 7, 13:16-41). Penulis Perjanjian Baru memakai Perjanjian Lama sebagai bagian yang besar dalam khotbah-khotbah mereka

\footnotetext{
16 Smith, Old Testament Theology .., 22-23.

17 J. Barton Payne, The Theology Of The Older Testament (Grand Rapids: Zondervan Publishing House, 1976), 25.

18 As the writer of the Law (2 Kings17:37; Hos.8:12), as a law in written form (Deut.17:14-20; 28:58, 61; 29:20f, 27; 30:10; 31:9-13, 19, 22, 24-26), is used without further explanation of where it is written (Ezra.3:4; Neh.8:15; 2 Chron.30:5, 18 cp. Ps. 149:9), Roger Beckwith, The Old Testament Canon of the New Testament Church (Grand Rapids, Michigan:1986), 68-69.

19 The teaching of the Psalmist that God's Word or Law is "settled for ever in heaven" (ps.119:89) find a ready response in the predestinarian mind of Essene writer of Jubilees, who conssequently refers to numerous injunctions of the Pentateuch, according to their Essene interpretation, as ordained or Written "on the heavenly tablets" (Jub.3:10, 31; 4:5, 3215:25; 16:29f; 18:18f; 28:6; 32:10, 15; 33:10, 12; 49:8), Ibid., 69.

$20 \quad$ Smith, Old Testament Theology,... 23.
} 
terhadap gereja mula-mula dalam Perjanjian Baru (Kis 2:16, 25; Mat $1: 22)^{21}$

Paulus, juga memakai Perjanjian Lama secara theologis, Ia mendukung pengajarannya tentang "pembenaran oleh Iman" dengan menunjuk kepada Habakuk 2:4 (baca Rm 4:3; Gal 3:6). Paulus juga mengutip dari sejumlah Mazmur sebagai pembuktian bahwa "seluruh manusia telah berdosa" (Rm 310-18). Para penulis Perjanjian Baru lainnya memakai Perjanjian Lama secara theologis, meskipun tidak satupun dari mereka yang mempresentasikan suatu theologia Perjanjian Lama, sebagaimana halnya Matius menunjuk kepada bagian-bagian Perjanjian Lama untuk meyakinkan orang Yahudi bahwa Yesus adalah Mesias. ${ }^{22}$ Pernyataan Perjanjian Baru yang jelas dalam pengajaran Tuhan Yesus dan para Rasul menjelaskan otoritas penyataan Allah dalam Perjanjian Lama, sebagaimana dikemukakan oleh Archer, This brief survey of the views of Christ and His apostles serve to indicate that regared the Old Testament in its entirety as the innerant record of God revelation to man. In Other words, the basic ground for the complete trustworthiness of scripture is the the trustworthiness of God Himself. ${ }^{23}$

Dengan demikian relevansi Perjanjian Lama nampak jelas baik dalam Perjanjian Lama, pada masa Intertestamen sampai kepada Perjanjian Baru. Penyataan Allah dalam Perjanjian Lama itu sendiri menjadi sumber theologia yang dipakai para penulis Alkitab, dan Perjanjian Lama dalam otoritasnya juga menjadi pokok pengajaran sampai kepada Perjanjian Baru.

\section{RELEVANSI PERJANJIAN LAMA BAGI GEREJA MASA KINI}

Mengacu kepada relevansi Perjanjian Lama dalam Perjanjian Lama itu sendiri dan juga relevansi Perjanjian Lama dalam Perjanjian Baru, menjadi dasar bagi kita untuk menguraikan relevansi Perjanjian Lama bagi pelayanan dan kehidupan gereja masa kini. Secara lebih tegas harus diulangi Mengapa Alkitab tetap relevan? Jawaban terhadap pertanyaan tersebut tidak ditentukan oleh pendapat para teolog, tetapi dari mana Alkitab itu berasal. Relevansi Alkitab terletak kepada Pribadi Allah yang menginspirasikan Alkitab itu melalui hamba-Nya pada masa lalu. Keyakinan terhadap Allah dan Firman-Nya (Alkitab) menjadi fondasi yang kuat bagi relevansi Alkitab pada masa kini.

Di dalam dunia yang tidak ingin dan tidak mampu mendengar, bagaimana kita dapat mendekatinya dengan khotbah sehingga didengar

\footnotetext{
$21 \quad$ Ibid., 24.

22 Smith, Old Testament Theology,... 24.

23 Gleason R Archer, A Survey Of Old Testament Introduction (Chicago: Moody Press, 1980), 27.
} 
secara efektif atau tetap relevan? Rahasia yang esensial bukan terletak kepada tehnik-tehnik penting, tetapi bagaimana pendengar diyakinkan akan landasan-landasan alkitabiahnya. Atau dengan kata lain, theologia lebih penting dari metodologi. Perlu ditegaskan bahwa homeletik sebagai bagian dari theologia praktika tidak dapat diajarkan tanpa suatu pondasi theologia yang kuat.Tentu khotbah memiliki prinsip-prinsip dan metode-metode, tetapi itu harus memiliki tujuan untuk menemukan apa yang terdapat didalamnya.

Jika kita memiliki dasar-dasar yang kokoh tentang kebenaran, maka kita akan dapat menyampaikan sesuatu yang sungguh-sungguh memiliki nilai rohani (theologis). John Stott dalam buku The art of Preaching in Twentieth century Between Two Worlds, menjelaskan lima pokok penting yang merupakan landasan-landasan theologis Perjanjian Lama sebagai bagian integral dari khotbah-khotbah masa kini antara lain: suatu keyakinan tentang Allah, suatu keyakinan tentang Alkitab, suatu keyakinan tentang Gereja, suatu keyakinan tentang jabatan Pastor (pastorate) dan suatu keyakinan tentang khotbah ${ }^{24}$

Dalam tulisan singkat ini penulis hanya menguraikan beberapa dari antaranya:

\section{A. Keyakinan Tentang Allah}

Konsep dasar tentang suatu relevansi Alkitab terletak pada doktrin tentang Allah. Suatu keyakinan tentang keberadaan-Nya, tindakan-Nya dan tujuan-Nya. Alkitab menjelaskan berbagai gambaran tentang Allah dengan cara yang beraneka ragam. Salah satu diantaranya ialah Allah sebagai terang.

Allah adalah Terang dapat berarti bahwa Allah sempurna dalam kekudusan-Nya, sehingga dalam Alkitab terang sering digambarkan sebagai kekudusan Allah yang bertentangan dengan gelap. Dalam tulisan Yohannes terang lebih sering digambarkan sebagai kebenaran. Sebagaimana ditegaskan bahwa "Yesus adalah terang dunia."

Dalam statemen Yohanes, Allah adalah terang dan di didalamnya tidak ada kegelapan, berarti Dia terbuka dan tidak ada rahasia dan Dia membuat dirinya diketahui. Seperti hakikat terang bersinar demikian juga Allah menyatakan diri-Nya sendiri. Dia memang menyembunyikan diri kepada orang-orang berhikmat dan pintar, tetapi itu dikarenakan oleh

24 Bagian-bagian ini penulis ringkaskan dari salah satu bab "theological foundation for Preaching" tulisan diuraikan oleh John R W Stott dalam bukunya The art of Preaching in Twentieth century Between Two Worlds, 93-132. 
penolakan mereka terhadap Yesus. Dengan demikain mengapa Yesus menyembunyikan diri terhadap mereka ialah karena mereka menyembunyikan diri terhadap Yesus.

Allah dari tempatnya yang maha tinggi menyatakan ide-ide-Nya yang dapat kita pahami sebagai sesuatu "komunikasi". memang pengenalan kita akan Allah tidaklah sama, tetapi Dia tidak memainkan suatu permainan "cari-sembunyi" (tak umpet) kepada manusia. Alkitab relevan dalam kehidupan masa kini, karena Alkitab yang bersumber kepada Allah bertujuan ingin menyampaikan tujuan Allah bagi manusia di segala tempat, waktu dan situasi. Kebenaran Allah tidak berubah, tidak dibatasi oleh ruang dan waktu. Apa yang dinyatakan oleh Allah melalui orang-orang pilihanNya dalam zaman mereka. Adalah kebenaran yang sama yang disampaikan kepada kita.

Relevansi Alkitab pada masa kini juga menjelaskan otoritas Firman Allah yang tidak berubah dari Allah yang tidak berubah.

\section{Allah Sudah Berkarya}

Alasan kedua mengapa Alkitab relevan pada masa kini, dilihat dari pribadi Allah yang sudah berinisiatif menyatakan diri-Nya, dan menyatakan kekuasaan-Nya kepada manusia. Allah yang telah menciptakan dunia dengan tangan-Nya sehingga setiap alam semesta menceritakan kemulianNya. Lebih dari situ, Allah telah menyatakan penebusan-Nya. Ketika manusia memberontak melawan Dia, Allah telah merencanakan suatu misi penyelamatan bagi manusia itu. Perjanjian Lama menjelaskan tiga rangkaian pembebasan Ilahi antara lain, pembebasan Abraham dari Ur, membebaskan Israel dari perbudakan di Mesir dan membebaskan Israel dari perbudakan di Babel. Pembebasan ini dibuat dalam suatu ikatan perjanjian , sehingga menjadikan mereka menjadi umat-Nya dan memberikan diri-Nya menjadi Allah mereka.

Dalam Perjanjian Baru penebusan Allah digenapi di dalam kelahiran, kematian dan kebangkitan anaknya Tuhan Yesus. Dengan demikan Allah Alkitab adalah Allah yang membebaskan umat manusia dari dosanya. Maksud-maksud Allah secara aktual itu dinyatakan melalui para nabi dalam Perjanjian Lama yang dilanjutkan oleh para rasul dalam Perjanjian Baru dan para hamba-Nya masa kini. Keselamatan yang dikerjakan oleh Allah adalah kebutuhan utama manusia yang masih tetap relevan sampai saat ini

Meragukan relavansi Firman Allah di dalam kehidupan masa kini sama halnya meragukan Allah yang dengan nyata-nyata sudah berkarya dan sedang berkarya sampai saat ini. Pertanyaan yang dapat dikemukakan kepada manusia yang tak percaya akan otoritas firman Allah pada masa kini 
ialah, "dimanakah Allah sedang tidak berkarya di tengah-tengah dunia ini?"

\section{Allah Sudah Berbicara}

Maksud Allah secara actual dinyatakan kepada umat-Nya melalui Firman-Nya. Para nabi secara tegas mengatakan bahwa, Fiman Allah telah datang" kepada mereka. Mereka memakainya untuk menghancurkan penyembah berhala, ilah-ilah memiliki mulut tetapi tidak dapat berbicara (Yes 15:15), tetapi suara Allah dapat mereka dengar dan mulut Allah sudah berbicara (Yes 40:5, 55:11). Hal penting lainnya ialah bahwa suara Allah berhubungan dengan aktifitas-Nya . Allah menjelaskan apa yang telah dikerjakannya. Mengapa Ia memanggil Abraham dari Ur, kemudian Dia berbicara tentang tujuan-tujuan-Nya dan memberikan janji-janji-Nya.

Mengapa Ia membebaskan Israel dari perbudakan di Mesir, kemudian Ia juga mengutus Musa untuk menjelaskan maksud-maksud-Nya bagi bangsa itu, untuk mejelaskan rencana-recana-Nya, untuk memberikan Hukum Taurat, dan mengajar mereka untuk beribadah.

Kecenderungan-kecenderungan theologia modern adalah menekankan aktifitas-aktifitas Allah secara historis tetapi menolak bahwa Allah sudah berbicara. Allah telah menyatakan diri melalui karya-Nya bukan dengan kata-kata atau pribadi bukan penyataan secara proposisional.

Alkitab menjelaskan bahwa Allah telah berbicara baik melalui perbuatan sejarah maupun melalui pekataan-perkataan-Nya.

\section{B. Keyakinan Tentang Alkitab}

Keyakinan tentang Allah secara langsung menunjuk kepada keyakinan tehadap Alkitab. Keyakinan terhadap Alkitab dapat dilihat dalam tiga hal yang berbeda yang satu dengan yang lainnya memiliki hubungan satu dengan yang lain :

\section{Alkitab adalah Firman Allah tertulis}

Firman Allah yang tertulis adalah definisi terhadap Alkitab. Allah telah menyatakan diri dalam sejarah tentang karya keselamatan yang mencapai puncaknya dalam firman yang telah menjadi manusia.

Mendefinisikan Alkitab sebagai firman Allah yang tertulis, yang telah berbicara tentang segala sesuatu dan telah diperintahkan oleh Allah untuk ditulis oleh nabi-nabi-Nya . Dia menaruh perkataan-Nya kepada pikiran manusia, sehingga jika kita mempercayai laporan Alkitab, sekaligus 
juga mempercayai apa yang telah dikatakan melalui utusan-utusan Allah.

\section{Alkitab Tetap Berbicara}

Alkitab bukanlah suatu koleksi dokumen-dokumen kuno yang tidak memiliki nilai pada masa kini, seperti fosil yang tinggal di dalam suatu museum. Alkitab adalah Firman Allah kepada manusia pada segala jaman dan di segala tempat. Alkitab tidak hanya berbicara bagi jamannya (ketika Alkitab ditulis), tetapi relevan bagi semua masa. Apa yang telah dikatakan dalam Alkitab pada jamannya adalah perkataan Allah yang tetap berlaku bagi kita untuk masa kini.

Para Rasul mempercayai apa yang telah dinubuatkan dalam Perjanjian Lama, mereka mamperkenalkan Alkitab dalam satu formula "gegraptai gar" atau "legei gar." Kedua kata ini menunjukkan peristiwa pada masa lalu dengan karangan masa kini. Apa yang telah dikatakan oleh Allah, sudah ditulis dan tetap menjadi suatu tulisan permanen.

Apa yang permanen? Dengan perkataan lain, Ia tetap berbicara tentang apa yang telah pernah dikatakan.

Contoh, Galatia 4:22, "Bukankah ada tertulis, bahwa Abraham memiliki anak." Dalam ayat-ayat sebelumnya Paulus telah berbicara, "apakah kamu tidak mendengar Hukum Taurat"? dan dalam ayat 30 Paulus juga berkata, "apa yang Alkitab katakan"? Disini nampak bahwa Alkitab dan Hukum Taurat adalah tulisan kuno. Bagaimana sebuah kitab tua dapat berbicara, kecuali Allah sendiri berbicara di dalamnya dan melaluinya.

Konsep tentang suara Allah yang relevan jaman sekarang ditekankan dalam Ibrani 3 dan 4; Penulis mengutip Mazmur 95, "hari ini jika engkau mendengar suara-Nya jangan keraskan hatimu." Penulis memperkenalkan kutipan dengan kata-kata "sebagaimana Roh Kudus katakan bahwa Roh Kudus ada pada hari ini."

\section{Keyakinan Tentang Gereja}

Banyak keyakinan mengenai gereja, namun satu keyakinan yang pasti, bahwa gereja merupakan ciptaan Allah oleh firman-Nya. Sebagaimana seluruh alam semesta, gereja bergantung kepada firman Allah. Allah bukan hanya menjadikan gereja melalui firman-Nya, namun juga memelihara, menopang, mengarahkan, menyucikan dan memperbaharuinya melalui firman-Nya.

Dalam konteks Perjanjian Lama Allah menetapkan perjanjian-Nya melalui Abraham,kemudian kepada keturunannya Ishak, Yakub dan bangsa Israel dengan syarat yang ditetapkan oleh Allah, "Jika engkau mengikuti 
segala firman-Ku (Kel 2:24; 19:3-6). Dan dalam pengalaman umat Tuhan sepanjang Perjanjian Lama, tema tentang ketaatan terhadap firman Tuhan akan menghasilkan berkat tetapi sebaliknya ketidaktaatan terhadap firman Allah akan mengakibatkan penghukuman menjadi tema yang tetap relevan dalam jaman itu dan tentu juga pada masa kini. Para Nabi yang menerima firman itu menasihatkan Israel untuk mendengar firman yang disampaikan.

Dalam Perjanjian Baru, para rasul yang menjadi juru bicara Allah juga mengklaim bahwa mereka sebagai pengemban firman Allah (1Tes 2:13). Para rasul yang dipilih dan diberikan otoritas oleh Kristus berbicara di dalam nama-Nya (Kristus) menghendaki supaya gereja-gereja mempercayai dan mentaati perintah-perintah-Nya. Sebagaimana surat kepada tujuh gereja, Ia memberikan instruksi,nasihat,menegur,mendorong dan memberi mereka janji-janji, peringatan-peringatan dan menghimbau mereka untuk mendengar, percaya, taat dan berpegang teguh sampai Ia datang.

Tentu para pengkhotbah masa kini bukanlah nabi atau rasul karena bukan penerima wahyu Allah secara langsung. Firman Tuhan tidak datang kepada kita sebagaimana nabi dan rasul, namun kita harus datang kepada firman Tuhan. Jika kita setia menyampaikan firman Allah, maka firman Allah yang ada ditangan dan dibibir kita akan dihidupkan oleh Roh Kudus di hati para pendengar kita. Firman Allah mutlak dibutuhkan bagi kesejahteraan gereja. Sejarah gereja telah menyediakan bukti akan hubungan antara gereja dan firman, antara status kristiani dan kualitas khotbah kristiani. Dekadensi dalam sejarah gereja terjadi ketika khotbah juga telah mengalami penurunan. E.C. Dargan dalam bukunya yang dikutip oleh John Stott antara lain menguraikan:

Kemerosotan kehidupan dan aktivitas spiritula dalam gereja-gereja umumnya disertai oleh khotbah yang tidak hidup, fomalitas, dan tidak menghasilkan buah ini sebagian sebagai sebab dan sebagian lagi sebagai akibat. Sebaliknya kebangunan rohani besar dalam sejarah gereja dapat ditelusuri secara lazim kepada karya mimbar, dan dalam prosesinya kebangunan-kebangunan rohani tersebut telah berkembang dan menjadi mungkin suatu tatanan khotbah yang baik. $^{25}$

Ada banyak yang dapat dikemukakan, tetapi suatu alasan yang pasti mengenai penurunan gereja dan ketidakdewasaan adalah sebagaimana yang disebut nabi Amos, suatu kelaparan mendengar firman Tuhan (8:11).

Dengan demikian, jika gereja ingin bertumbuh kembali, tidak ada kebutuhan yang lebih besar selain daripada suatu pemulihan khotbah yang 
Alkitabiah, penuh kuasa dan setia.

Pada bagian akhir dari tulisan ini penulis menguraikan secara singkat signifikansi teks-teks Perjanjian Lama bagi pelayanan gereja yang nampak dalam khotbah-khotbah yang bersumber pada Perjanjian Lama.

\section{KHOTBAH DARI PERJANIAN LAMA}

1. Khotbah dari Perjanjian Lama memiliki nilai karena Perjanjian Lama merupakan satu bagian Alkitab seperti Perjanjian Baru. Seluruh Firman Allah penting bagi proklamasi tentang keselamatan (2Tim 3:1617). Alkitab tidak lengkap tanpa Perjanjian Lama. Perjanjian Lama adalah bagian penting yang dipakai oleh Tuhan Yesus. Ia mengajarkan Perjanjian Lama (Yes 61:1-2=Luk 4:16-22), Perjanjian Lama diinspirasikan oleh Allah, sempurna seperti halnya Perjanjian Baru, sehingga Yesus tidak meniadakan satu "iota" pun dari Perjanjian Lama (Mat 5:18). Para rasul mengakui dan memberitakan Perjanjian Lama dalam pelayanan mereka. Contoh: Khotbah Petrus (Kis 2:17-20 dikutip dari Y1 2:28-32; Kis 2:25-28 dari Mzm 16: 8-11). Pelayanan Rasul Paulus (Rm 9) Dia mendiskusikan hubungan hukum Taurat dan Injil, Dia mengutip dari Perjanjian Lama (Kel 5:2, 7:3; Hos 1:10, 2:23; Yes 1:9, 10:22-23 = Rm 9:15, 17, 25-29).

2. Khotbah Perjanjian Lama memiliki nilai untuk masa kini. Perjanjian Lama adalah landasan bagi doktrin dan perkembangan Iman. Ajaran Perjanjan Baru tidak muncul begitu saja sebagai sejarah yang kosong. Yesus datang dalam kegenapan waktu. Firman Allah (Perjanjian Lama) merupakan penuntun bagi kedatangan-Nya. Galatia 4:4-5 -> persiapan bagi pekerjaan penebusan. Hukum taurat digenapi suatu fungsi penting sebagai penuntun yang membawa kepada Kristus (Gal 3:24).

Bagian-bagian Perjanjian Lama banyak ditemukan dalam Perjanjian Baru. Lebih dari 1300 dikutip langsung dari Perjanjian Lama. Seseorang boleh saja, mengkhotbahkan bahwa "Kristus adalah kurban paskah yang dipersembahkan bagi kita (1Kor 5:7). Studi kita tidak lengkap tanpa melihat dan mempelajari Keluaran 12 dan 13 dalam Perjanjian Lama. Ketika kita mengkhotbahkan bagian-bagian seperti "hari penebusan" (Im 16) atau "paskah" (Kel 12), kita menghargai panggilan Kristus sebagai dasar kebenaran-kebenaran Perjanjian Baru tentang iman dan keselamatan.

3. Khotbah-khotbah Perjanjian Lama merupakan latar belakang pelayanan 
Juruselamat. Contoh: Tipologi yang digambarkan pribadi dan Pelayanan Tuhan Yesus. Paulus menjelaskan maknanya dalam suratnya kepada jemaat Kristus (1Kor 10:1-4, 6). Air dari batu karang (Kel 17:17; Bil 20:2-13), adalah satu tipe tentang Kristus. Manna (Yos 6:31-52; Kel 16:12-36), ular tedung di padang gurun (Bil 21:4-9; Yoh 3:14-15) menunjukkan kepada Kristus. Binatang-binatang kurban dan pencurahan darah adalah tipe Kristus (Im 16:1-34; 17:10-12). Kristus menggenapi semua hukum Taurat (Mat 5:17), Kristus penggenapan Imam besar (Ibr 10:7). Tanpa khotbah dan penyampaian Kebenaran yang agung ini, im Perjanjian Lamaikasi tentang penebusan Kristus hanya sebagai teka-teki yang membingungkan.

4. Khotbah dari Perjanjian Lama memiliki nilai, karena sifat dan tindakan Allah secara jelas dinyatakan. Perjanjian Baru menjelaskan bahwa Allah adalah Allah yang kudus, tetapi dalam Perjanjian Lama kita mendengar tentang hakikat sesuatu yang kudus (Kel 15:11; Mzm 47:8, 48:1; Am 4:2).

Pentateukh $->$ mengajarkan hukum Allah, yang dituntut bagi setiap orang. Yosua $\rightarrow$ menunjukkan bahwa kekuatan Allah dapat menundukkan lawan. Hakim-hakim $\rightarrow$ mengingatkan akibat-akibat dosa. Rut -> menyatakan konsep tentang penebusan kaum kerabat dll.

Kedudukan Israel dalam sejarah penebusan tidak dapat dipahami tanpa melihat kepada bagian-bagian Alkitab (Kej 12:1-3; Kel 19:1-6; Yos 24:1-29; Yes 54:1-17, 66:1-24; Yeh 33:11-16; Zak 12:1-13.

5. Perjanjian lama menyediakan ilustrasi-ilustrasi yang hidup dan menarik. Perjanjian Lama merupakan buku yang menyediakan berbagai ilustrasi kehidupan manusia. Kain dan Habel $\rightarrow$ gambaran tentang kemarahan manusia yang berakibat fatal. Daud dan Yonathan $>$ persahabatan yang sejati. Rut dan Naomi -> persahabatan antara mertua dan menantu yang sejati dan lain-lain.

Tulisan ini sekiranya dapat menjadi jawaban atas pertanyaan yang sering kali muncul dalam studi theologia maupun dalam kehidupan dan pelayanan gereja secara praktis. Perjanjian Lama adalah firman Allah yang tetap relevan bagi kehidupan dan pelayanan gereja bagi masa kini. Perjanjian Lama menjadi sumber pengajaran yang signifikan dan menjadi sarana bagi pertumbuhan gereja yang kuat. Solideo gloria! 


\section{KEPUSTAKAAN}

Erickson, Millard J.

1985 Christian Theology. Michigan: Baker Book House Company. Gwaang-Ho, Jeohn

2001 Sains Penciptaan. Bandung: Institut Alkitab Tiranus.

Hasel, Gerhard F.

1972 Old Testament Theology: Basic Issues in The Current Debate. Michigan: WM. B. Eerdmans.

Hayes, John H. \& Prussner Frederick

1985 Old Testament Theology its History \& Development. Atlanta: John Knox Press.

Mayo, M.S.,

1981 The Relevance of Old Testament for Christian Facts. America: University Press.

Payne, Barton J.

1976 The Theology Of The Older Testament. Michigan: Zondervan Publishing House.

Pratt, Richard L. Jr.

2005 He Gaves Us Story (Ia Berikan Kita Kisah-Nya). Surabaya: Momentum.

Sailhamer, John H.

1995 Introduction to Old Testament Theology. Michigan: Zondervan Publishing House.

Smith, Ralph L.

1992 Old Testament Theology Its History, Method, and Message. Nashville: Broadman and Holman Publisher.

Stott, John W.R.

1981 Between Two Worlds, The Art of Preaching in the Twentieth

Century. Michigan: William B. Eerdmans Publishing Company.

Majalah/Artikel:

Pane Batara,

2002 "Berlarilah Seperti Yusuf dari Istri Potifar." Dalam DIA Edisi No.3 Tahun XVII hal. 14-16 Jakarta: Perkantas.

Rendakasiang Daltur

2002 “Mengubah Katak Menjadi Daniel." Dalam DIA Edisi No.4

Tahun XVII hal. 5, Jakarta: Perkantas. 